\title{
candr. \\ Combined Toxicity of Gas Plasma Treatment and Nanoparticles Exposure in Melanoma Cells In Vitro
}

\author{
Sander Bekeschus
}

check for updates

Citation: Bekeschus, S. Combined Toxicity of Gas Plasma Treatment and Nanoparticles Exposure in Melanoma Cells In Vitro. Nanomaterials 2021, 11, 806. https://doi.org/10.3390/ nano11030806

Academic Editors:

Abdelhamid Elaissari and Pawel Pohl

Received: 20 February 2021

Accepted: 18 March 2021

Published: 22 March 2021

Publisher's Note: MDPI stays neutral with regard to jurisdictional claims in published maps and institutional affiliations.
ZIK plasmatis, Leibniz Institute for Plasma Science and Technology (INP), Felix-Hausdorff-Str. 2, 17489 Greifswald, Germany; sander.bekeschus@inp-greifswald.de; Tel.: +49-3834-554-3948

\begin{abstract}
Despite continuous advances in therapy, cancer remains a deadly disease. Over the past years, gas plasma technology emerged as a novel tool to target tumors, especially skin. Another promising anticancer approach are nanoparticles. Since combination therapies are becoming increasingly relevant in oncology, both gas plasma treatment and nanoparticle exposure were combined. A series of nanoparticles were investigated in parallel, namely, silica, silver, iron oxide, cerium oxide, titanium oxide, and iron-doped titanium oxide. For gas plasma treatment, the atmospheric pressure argon plasma jet kINPen was utilized. Using three melanoma cell lines, the two murine non-metastatic B16F0 and metastatic B16F10 cells and the human metastatic B-Raf mutant cell line SK-MEL-28, the combined cytotoxicity of both approaches was identified. The combined cytotoxicity of gas plasma treatment and nanoparticle exposure was consistent across all three cell lines for silica, silver, iron oxide, and cerium oxide. In contrast, for titanium oxide and iron-doped titanium oxide, significantly combined cytotoxicity was only observed in B16F10 cells.
\end{abstract}

Keywords: B16; gas plasma technology; kINPen; plasma medicine; reactive oxygen and nitrogen species; RNS; ROS; SK-MEL-28

\section{Introduction}

Despite continuous advances in therapy, cancer remains a deadly condition. In 2020 in the US alone, 1.8 Mio new cancer cases were diagnosed, while more than 600,000 people died due to the malignant disease [1]. Among all types of cancers, skin cancer has the highest incidence globally, especially in Caucasians [2]. Typical risk factors include solar radiation, age, and skin phototype [3]. The highest mortality among skin cancer is attributed to malignant metastatic melanoma. This type of cancer has the highest mutation rate among all malignancies [4], making it especially difficult to treat because therapyresistance often arises against many types of therapeutic approaches. This is also why melanoma is often used as a so-called model tumor, meaning that if therapies succeed against melanoma, they are likely to perform well in other cancer entities, too. The onset of the new age and checkpoint-immunotherapy success is an excellent example of this [5], and the state-of-the-art views on melanoma diagnosis and therapy have been outlined recently [6-8]. Nevertheless, many patients do not benefit from therapy, establishing the need to optimize treatment strategies further.

In the past years, gas plasma technology emerged as a novel tool to target tumors, especially skin [9]. It mainly acts via the deposition of reactive oxygen and nitrogen species (ROS/RNS), placing the field of plasma medicine-which has been reviewed recently [10-12] — in the heart of redox biology [13]. Several studies have underlined the anti-melanoma effects of gas plasma treatment in vitro and in vivo [14-16]. A more established innovative anti-melanoma approach is the use of nanotherapeutics such as nanoparticles [17]. The benefit of nanoparticles is the broad types of materials used together with a range of different functionalizations [18]. Their putative application for medical purposes has been recently summarized [19-21]. We here combined gas plasma treatment 
with nanoparticle exposure in three melanoma cell lines and found combined cytotoxicity in five out of seven nanoparticle types investigated.

\section{Materials and Methods}

\subsection{Cell Culture}

The melanoma cell lines B16F0 (ATCC CRL-6322, non-metastatic cell line), B16F10 (ATCC CRL-6475, metastatic cell line), and SK-MEL-28 (ATCC HTB-72, metastatic cell line) were cultured in Roswell Park Memorial Institute (RPMI1640) medium supplemented with $10 \%$ fetal bovine serum, $2 \%$ penicillin/streptomycin, and $1 \%$ glutamine (all Sigma, Taufkirchen, Germany). Cell lines were split two to three times per week and incubated under standard conditions at $37^{\circ} \mathrm{C}, 95 \%$ humidity, and $5 \% \mathrm{CO}_{2}$ (Binder, Tuttlingen, Germany).

\subsection{Nanoparticle and Plasma Treatment}

Nanoparticle acquisition or preparation and solvation was done as previously reported [22]. One day before the experiment, $1 \times 10^{4}$ cells were seeded in $100 \mu \mathrm{L}$ of fully supplemented cell culture medium in 96-well flat-bottom culture plates (Nunc, Roskilde, Denmark) and allowed to adhere overnight. Before treatment, the cell culture medium was taken off, and $50 \mu \mathrm{L}$ of fresh and fully supplemented cell culture medium was added. The nanoparticles used in this study (Table 1 ) were silica nanoparticles, both small ( $\left.\mathrm{Si}_{30}\right)$ and larger sizes $\left(\mathrm{Si}_{150}\right)$, and metal oxide nanoparticles, including silver $(\mathrm{Ag})$, iron oxide $(\mathrm{FeO})$, cerium oxide $\left(\mathrm{CeO}_{2}\right)$, titanium oxide $\left(\mathrm{TiO}_{2}\right)$, and $10 \%$ iron-doped titanium oxide $\left(\mathrm{FeTiO}_{2}\right)$. All nanoparticles were stored at $4{ }^{\circ} \mathrm{C}$ and thoroughly vortexed before their use. Nanoparticles were prepared at indicated concentrations in $50 \mu \mathrm{L}$ of fully supplemented cell culture medium and added to the cells at the final concentration indicated in the figure legend and immediately before plasma treatment. For plasma treatment, the atmospheric pressure argon plasma jet kINPen was used with argon (99.9999\% pure; Air Liquide, Greifswald, Germany) as feed gas at two standard liters per minute. The jet was operated at a frequency of $1 \mathrm{MHz}$, and its technical details have been reviewed before [23,24]. For the cells' treatment, the jet was attached to a computer-controlled $x y z$ motorized stage with predetermined parameters for the center position, treatment height, and treatment times for each of the wells as recently described [25].

Table 1. Types and properties of nanoparticles investigated in this study.

\begin{tabular}{ccc}
\hline Type of Nanoparticle & Hydrodynamic Diameter in Water (nm) & Zeta Potential \\
\hline Silica (Si) nanoparticles & & \\
$\mathrm{Si}_{30}$ & 33 & -15 \\
$\mathrm{Si}_{150}$ & 141 & -21 \\
Metal oxide nanoparticles & 12 & -29 \\
$\mathrm{Ag}$ & 200 & -20 \\
$\mathrm{FeO}$ & 135 & -49 \\
$\mathrm{CeO}$ & 466 & -36 \\
$\mathrm{TiO}_{2}$ & 216 & -44 \\
$\mathrm{FeTiO}_{2}$ & &
\end{tabular}

\subsection{Microscopy}

Selected conditions were imaged using an Operetta CLS high-content imaging device (PerkinElmer, Hamburg, Germany). Brightfield and digital phase contrast were imaged using a 5x air objective (NA: 0.16; Zeiss, Jena, Germany) and overlaid for display.

\subsection{Metabolic Activity}

To analyze metabolic activity, $50 \mu \mathrm{L}$ of fully supplemented cell culture medium containing resazurin (Sigma, Taufkirchen, Germany) at a final concentration of $100 \mu \mathrm{M}$ was added to the cells. Resazurin freely diffuses into cells, where it is reduced by nicotinamide adenine dinucleotide phosphate (NADPH) to its fluorescent product, resorufin. After $4 \mathrm{~h}$ 
of incubation, the plate was transferred to an F200 microplate reader (Tecan, Männdedorf, Switzerland), and resorufin fluorescence was quantified at $\lambda_{\mathrm{ex}} 535 \mathrm{~nm}$ and $\lambda_{\mathrm{em}} 590 \mathrm{~nm}$. For each cell line, the relative fluorescence units obtained were normalized to the respective untreated controls.

\subsection{ROS Quantification}

For analysis of the short-lived ROS deterioration product hydrogen peroxide $\left(\mathrm{H}_{2} \mathrm{O}_{2}\right)$, $100 \mu \mathrm{L}$ of phosphate-buffered saline (PBS) was exposed to gas plasma as described above. To control the assay's specificity, N-acetylcysteine (NAC, 2 mM; Sigma, Taufkrichen, Germany) or catalase ( $5 \mu \mathrm{g} / \mathrm{mL}$; Sigma, Taufkirchen, Germany) was added before plasma treatment to scavenge ROS and $\mathrm{H}_{2} \mathrm{O}_{2}$, respectively. Untreated and argon (Ar) gas-treated PBS was used as negative controls. Quantification with amplex ultra red (ThermoFisher, Bremen, Germany) was done as described before [26].

\section{Results}

This study aimed to investigate the combined cytotoxicity of gas plasma treatment and nanoparticles in three melanoma cell lines in vitro. To this end, silica nanoparticles of two sizes (i.e., $\mathrm{SI}_{30}$ and $\mathrm{Si}_{150}$ ) and metal oxide nanoparticles that included silver, iron oxide $(\mathrm{FeO})$, cerium oxide $\left(\mathrm{CeO}_{2}\right)$, titanium oxide $\left(\mathrm{TiO}_{2}\right)$, and $10 \%$ iron-doped titanium oxide $(\mathrm{FeTiO} 2)$ were utilized (Table 1$)$. After exposure to nanoparticles, the overall growth pattern of non-metastatic murine B16F0, metastatic murine B16F10, and metastatic human SK-MEL-28 (Figure 1) cells was reduced when investigated $16 \mathrm{~h}$ after particle addition. To next see whether nanoparticle toxicity followed a dose-dependent pattern, a serial dilution of particles was added to the B16F0 (Figure 2a), B16F10 (Figure 2b), and SK-MEL28 (Figure 2c) cells, and the metabolic activity was investigated $24 \mathrm{~h}$ later, confirming a concentration-dependent cytotoxic effect in a pilot experiment. Subsequently, we tested the combined efficacy of gas plasma treatment with nanoparticle exposure, with the data differing to a minor extent from those obtained in the pilot experiments. In B16F0 cells, gas plasma treatment alone ( $20 \mathrm{~s}$ treatment time) reduced the metabolic activity by approximately $50 \%$ when investigated at $24 \mathrm{~h}$, while exposure to the seven different types of nanoparticles $(10 \mu \mathrm{g} / \mathrm{mL})$ was lesser than that (Figure 3a). Upon combination of nanoparticle exposure immediately followed by gas plasma treatment, significantly increased combined cytotoxic effects were observed for $\mathrm{Si}_{30}, \mathrm{Si}_{150}, \mathrm{Ag}, \mathrm{FeO}$, and $\mathrm{CeO}_{2}$ but not $\mathrm{TiO}_{2}$ and $\mathrm{FeTiO}_{2}$ nanoparticle-gas plasma combination treatments. In B16F10 cells, the results were overall similar to those found in the $\mathrm{B} 16 \mathrm{~F} 0$ cells, with the exception of $\mathrm{TiO}_{2}$ and $\mathrm{FeTiO}_{2}$ nanoparticle-gas plasma combination treatments showing a significantly increased cytotoxicity when compared to gas plasma treatment alone (Figure 3b). In SK-MEL-28, the gas plasma treatment alone was more cytotoxic than in the murine cell lines, while the combination effects were similar to those found in the B16F0 cells (Figure 3c). Finally, a treatment time-dependent ROS generation of gas plasma was found (Figure 4). 

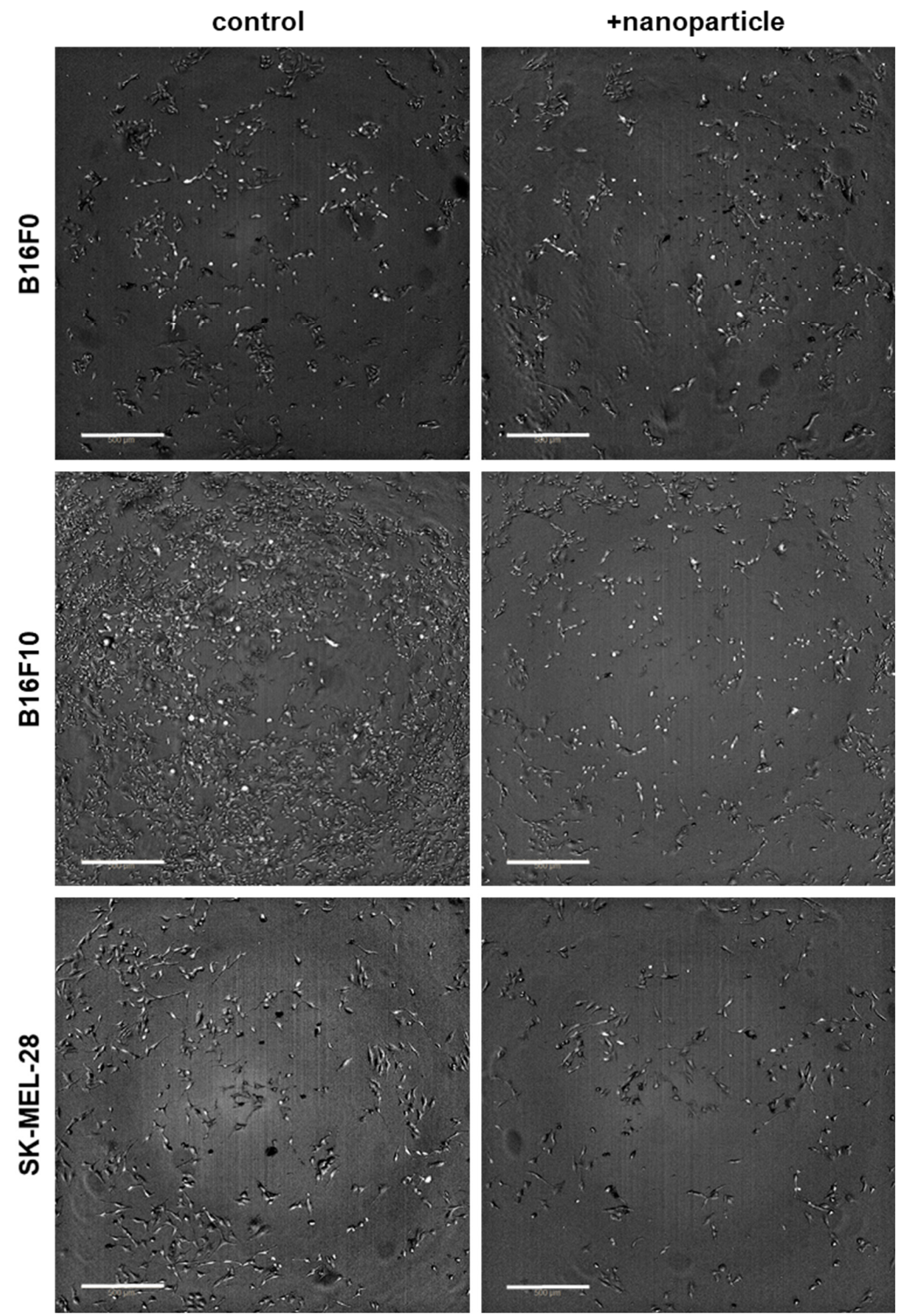

Figure 1. Microscopic images of melanoma cell lines used in this study. Shown are images of B16F0, B16F10, and SK-MEL-28 cells exposed to $\mathrm{TiO}_{2}$ particles. The cells were untreated (left images) or exposed to nanoparticles (right images). Images were acquired $16 \mathrm{~h}$ later and show overlays of brightfield and digital phase-contrast imaging. Scale bar $=500 \mu \mathrm{m}$. 
a
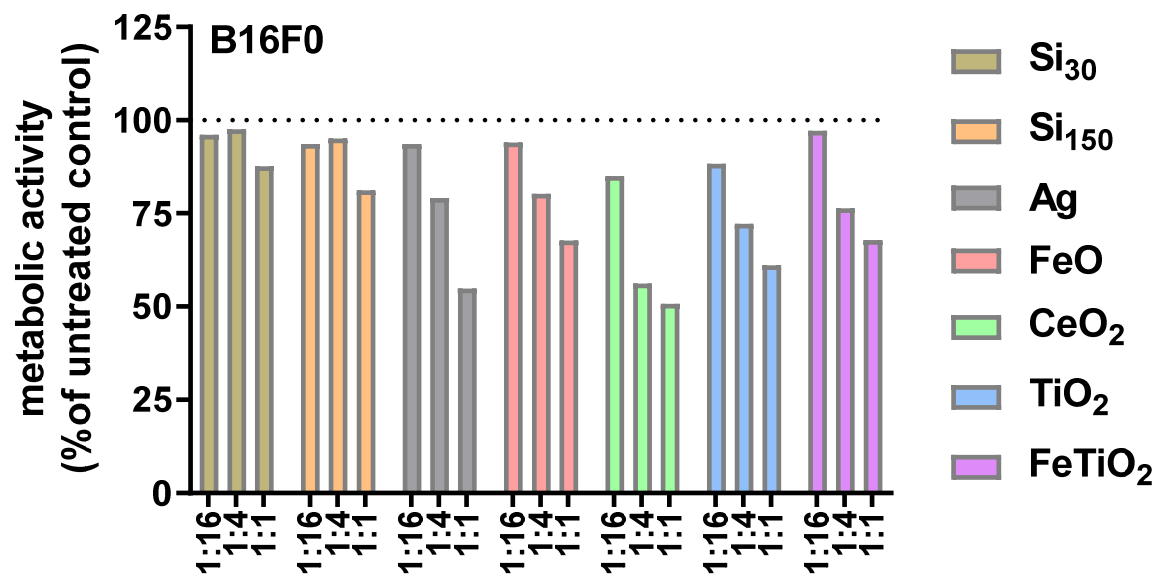

b

dilution
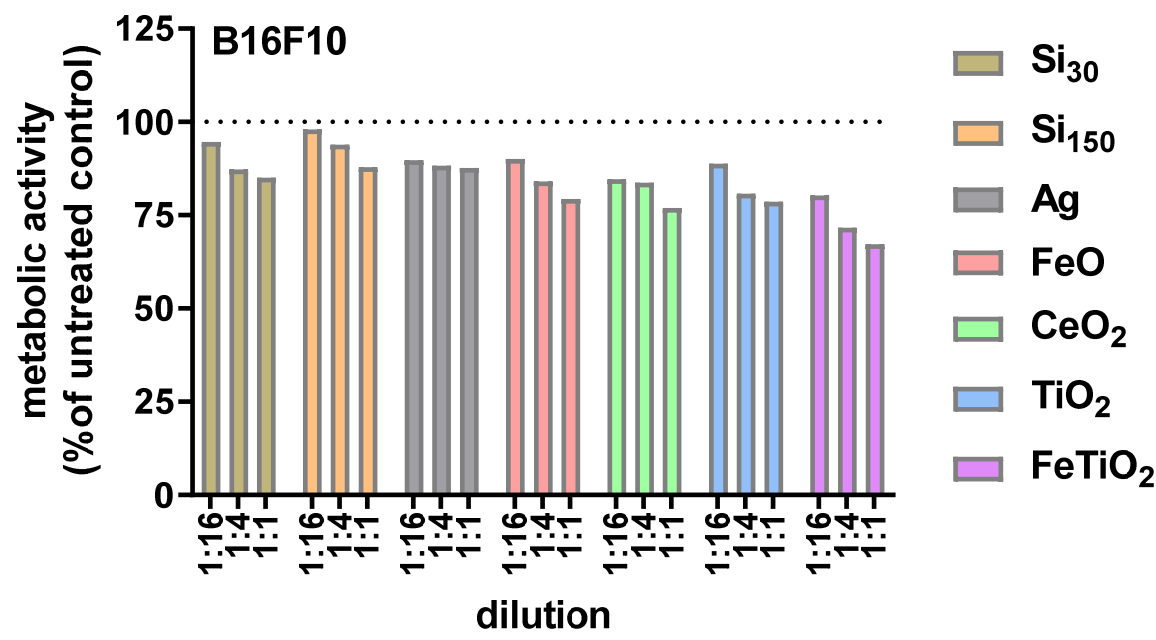

C

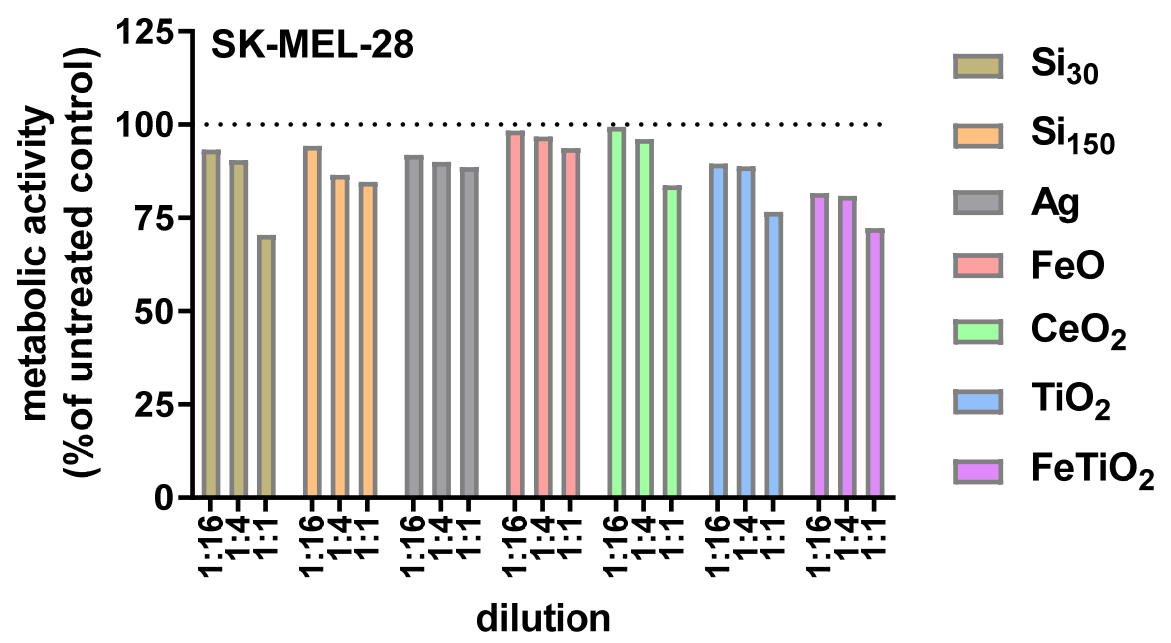

Figure 2. Concentration-dependent effects of nanoparticles. B16F0 (a), B16F10 (b), and SK-MEL-28 (c) cells were cultured with nanoparticles or were left untreated. At $24 \mathrm{~h}$, the metabolic activity was determined using a resazurin-based assay, and data were normalized to that of untreated control cells. The top particle concentration (1:1) was $10 \mu \mathrm{g} / \mathrm{mL}$. Data are from one pilot experiment. 
a

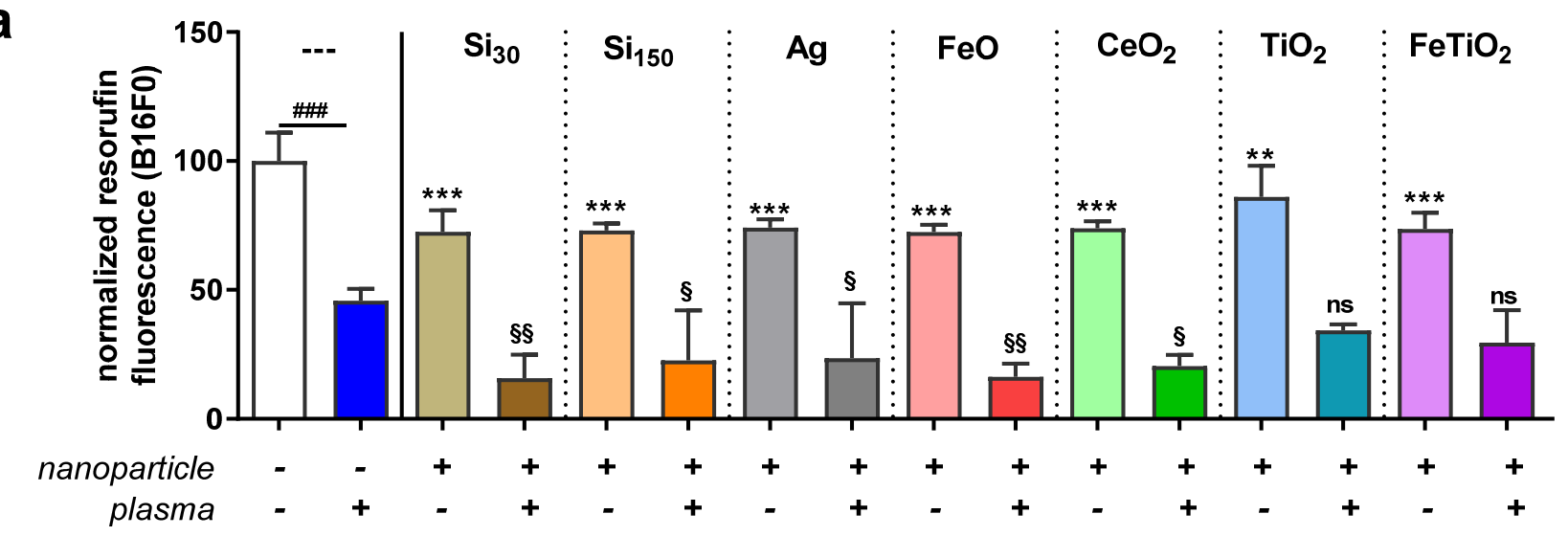

b

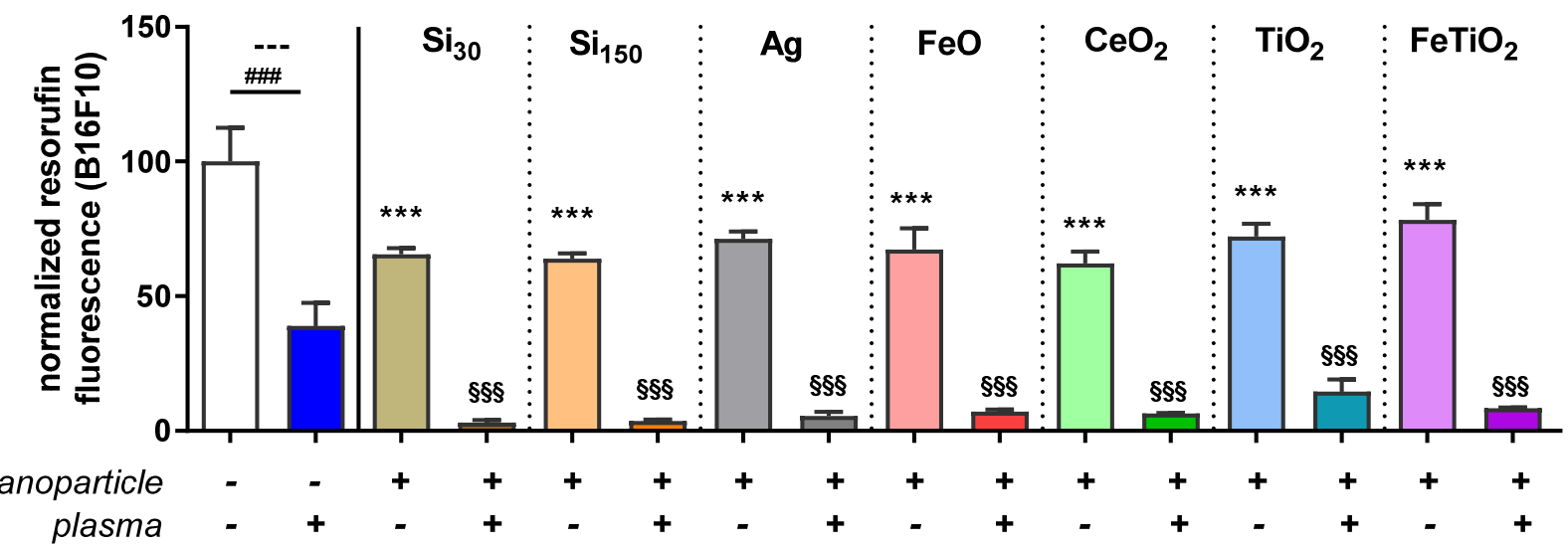

C

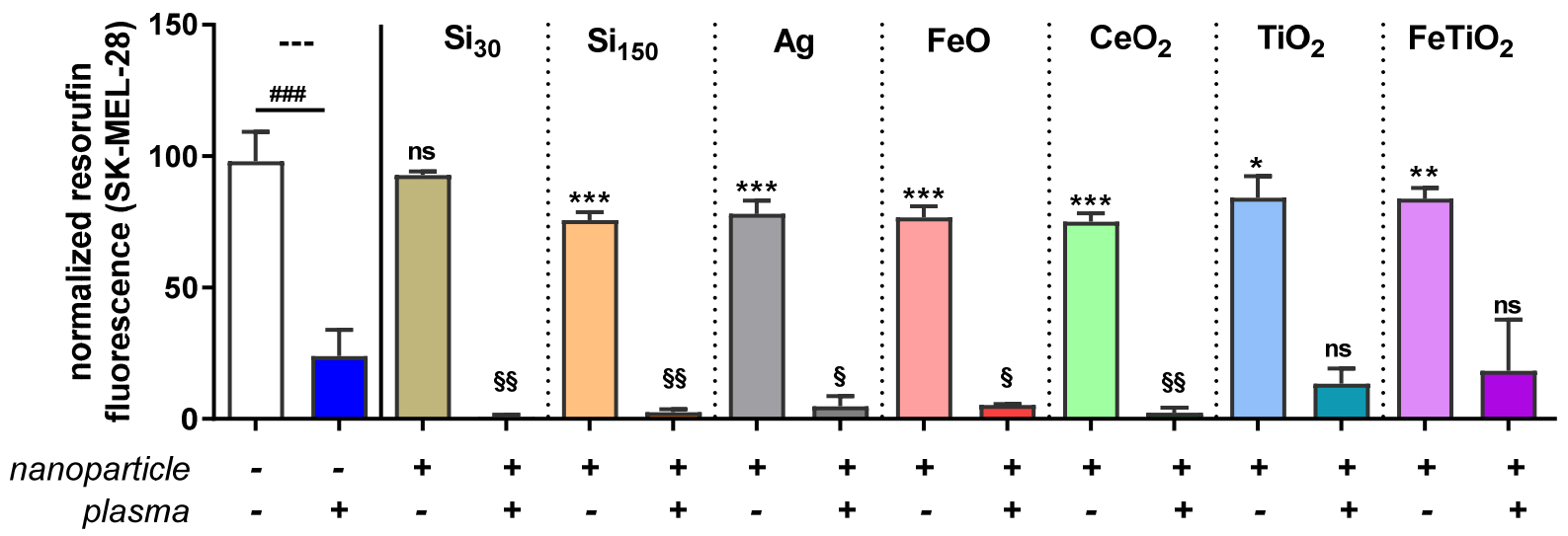

Figure 3. Combined cytotoxicity of nanoparticle exposure and gas plasma treatment. B16F0 (a), B16F10 (b), and SK-MEL-28 (c) cells were exposed to nanoparticles $(10 \mu \mathrm{g} / \mathrm{mL})$ immediately followed by gas plasma treatment. Data are the mean and standard error from three experiments comparing all nanoparticle samples without gas plasma treatment to vehicle control without gas plasma treatment (asterisks: ${ }^{*}$ ) and all nanoparticle samples with gas plasma treatment to vehicle control with gas plasma treatment (paragraph symbols: §) using one-way analysis of variance, and untreated vehicle controls versus gas plasma-treated vehicle control (hashtag: \#) using the $t$-test. 


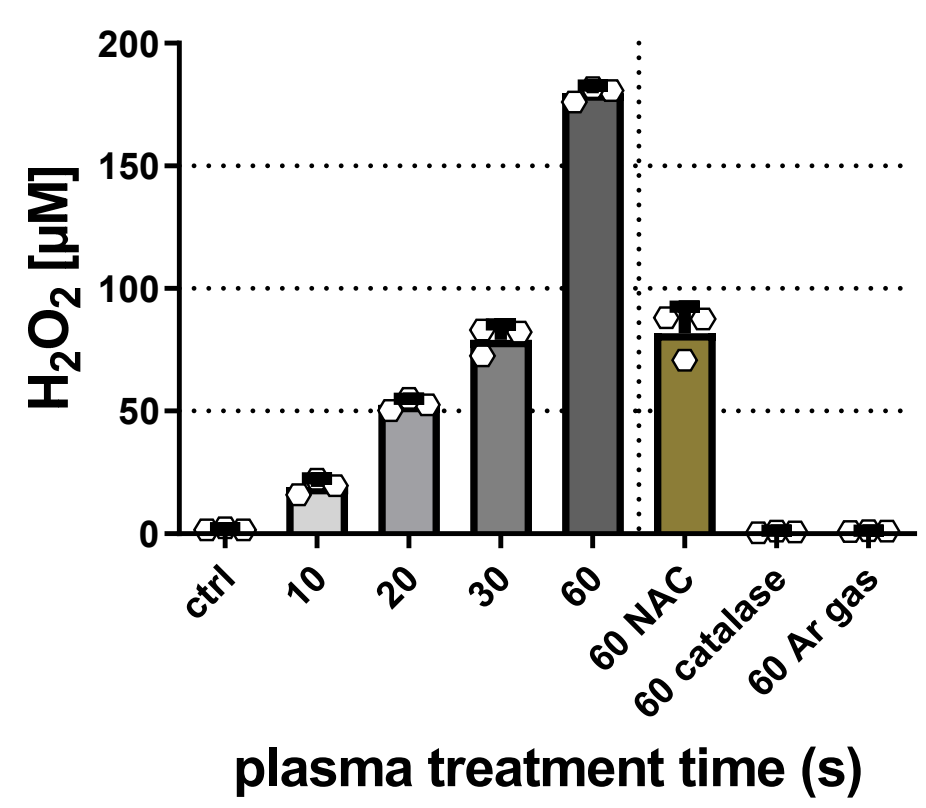

Figure 4. Reactive oxygen species (ROS) generation via gas plasma treatment. Phosphate-buffered saline (PBS) was exposed to gas plasma for $10 \mathrm{~s}, 20 \mathrm{~s}, 30 \mathrm{~s}$, and $60 \mathrm{~s}$, with the latter in the presence or absence of catalase or n-acetylcysteine (NAC), before quantification of hydrogen peroxide $\left(\mathrm{H}_{2} \mathrm{O}_{2}\right)$. Untreated PBS and PBS exposed to argon gas alone (plasma: off) served as negative controls.

\section{Discussion}

This study investigated the combined effect of gas plasma treatment and seven types of nanoparticles in three melanoma cell lines and found the combined toxicity of both treatment modalities. While combining nanoparticles and plasma is not necessarily novel by itself, the usage of several types and investigation of several cell types might be a valuable contribution to some researchers following such an approach.

Nanoparticle toxicity in melanoma cells has been described for several nanoparticle types. For example, silver nanoparticles were previously added to B16 melanoma cells, and dose-dependent cytotoxicity and intracellular ROS production were reported [27]. Along similar lines, silica nanoparticles were found to exert cytotoxic activity in murine melanoma cells as well [28]. Analogous findings were obtained for FeO nanoparticles [29] as well as $\mathrm{CeO}_{2}$ particles, with the latter having the unique feature of acting as both radio-protectors and radio-sensitizers when combined with radiotherapy [30]. $\mathrm{TiO}_{2}$, in turn, has been reported to be a ROS-promoting agent that, in combination with photoactivation, shows promising anticancer activity [31]. An anti-melanoma effect of $\mathrm{Fe}-\mathrm{TiO}_{2}$ has not been reported so far and was more pronounced in B16F0 compared to B16F10 cells. Both cell types differ more than 100 fold in their capacity to form lung nodules in vivo, which ultimately correlates with overall survival in mice [32]. On the molecular level, the increased metastatic potential of B16F10 was attributed to the expression of the acidic actin $\beta \mathrm{m}$, which results in enhanced invasiveness in collagen and cell motility in vitro, and ultimately also in vivo [33]. The B16F10 cells are also characterized by a weaker vinculin expression [34], which is turn is an adapter protein for, e.g., integrins to promote cell adhesion and non-invasiveness [35].

It is interesting to note that an ROS promotion or potentiation has been described with nanoparticle exposure in melanoma cells. Gas plasma systems are equally capable of generating delicate mixes of ROS/RNS that, in contrast to nanoparticles and pharmacological agents, target the tumor cells from the extracellular milieu [36]. Hence, several groups have tested the combined toxicity of nanoparticle and gas plasma before, albeit commonly only using a single type of nanoparticle $[37,38]$. For instance, gold nanoparticles were found to combine with gas plasma-mediated cytotoxicity in G361 melanoma cells [39], and similar results were obtained in glioblastoma cells [40] and human HCT-116 colorectal 
cancer cells [41] in vitro. Even more, gas plasma treatment was proposed to accelerate the uptake of gold nanoparticles into glioblastoma cells in two separate studies [42,43]. Investigating the combined toxicity of gold nanoparticles and gas plasma treatment in human U937 lymphoma cells, it was shown that the combined effect was a result of intracellular glutathione (GSH) depletion and modulation of oxidative stress [44]. As a mechanism of action, it has been noted many times that gas plasma treatment generates several types of short-lived ROS/RNS in the plasma gas phase, which subsequently enter the bulk liquid and finally - in the absence of target biomolecules-deteriorate to long-lived species [45]. The levels of $\mathrm{H}_{2} \mathrm{O}_{2}$ were measured in PBS that does not contain proteins, and hence the measurements overestimated the final $\mathrm{H}_{2} \mathrm{O}_{2}$ concentration compared to fully-supplemented cell culture medium by about 30\% [25]. Nevertheless, at sufficient concentrations, the gas plasma-derived ROS/RNS promotes tumor cell inactivation [46], which was proposed to engage, e.g., mitochondrial stress [47-49] and target antioxidant defense mechanisms [50-52]. While a range of modes of action has been described for nanoparticle-mediated cytotoxicity, both mitochondrial alterations and ROS production are frequently observed phenomena [53-55], which may have contributed to the combined cytotoxicity found in this study. This combined toxicity was less pronounced in the $\mathrm{TiO}_{2}$ and $\mathrm{FeTiO}_{2}$ combination regimens, and the reasons for this remain the subject of future studies.

In this study, particular combined toxicity was found for iron, cerium oxide, silica, and silver nanoparticles. For iron nanoparticles, combined toxicity with gas plasma treatment was previously found in breast cancer cells in vitro [56]. Studies using both gas plasma exposure and cerium oxide nanoparticles have not been reported yet. A range of studies are available for silver nanoparticles, demonstrating combined cytotoxicity with gas plasma treatment in Hs 294T human melanoma cells [57] and even antimicrobial efficacy in bacterial phytopathogens [58]. Gas plasma exposure in glioblastoma cells also led to enhanced silver nanoparticle uptake rates and enhanced cytotoxicity [59]. The combined use of silica nanoparticles, especially with the two different sizes used here, with gas plasma for cancer treatment has not been reported so far.

While it was hypothesized to see combined toxicity with the types of particles used in combination with plasma treatment, other types, such as non-toxic gold nanoparticles, would have been interesting to investigate as well. Future studies would also benefit from intracellular ROS measurements and kinetic ROS monitoring during plasma or nanoparticle treatments to clarify ROS's involvement to a more considerable extent. Moreover, combination treatments with a range of plasma treatment times and isobologram analysis might reveal additional effects that are lacking in the current study due to the single plasma treatment time used. Monitoring nanoparticle uptake might give additional insight into the toxicity mechanisms observed in this study. Subsequent studies are warranted to elaborate on the mechanistic action and in vivo relevance of these findings.

\section{Conclusions}

A combined cytotoxic effect of gas plasma treatment and five types of nanoparticles was found in three melanoma cell lines in vitro. In this setting, silica, silver, iron oxide, and cerium oxide particles gave the best responses across all cell lines.

Funding: This work was funded by the Federal German Ministry of Education and Research (BMBF), grant numbers 03Z22DN11 and 03Z22Di1.

Institutional Review Board Statement: Not applicable.

Data Availability Statement: The data presented in this study are available on request from the corresponding author.

Acknowledgments: Technical support by Maxi Lippert and Felix Nießner is gratefully acknowledged. Nanoparticles and particle characterization were kindly provided by Dominic Docter (formerly Mainz University Medical Center, Germany). 
Conflicts of Interest: The author declares that there is no conflict of interest regarding the publication of this paper.

Ethical Statement: The cell lines B16F0, B16F10, and SK-MEL-28 were all obtained from ATCC (numbers CRL-6322, CRL-6475, and HTB-72, respectively).

\section{References}

1. Siegel, R.L.; Miller, K.D.; Jemal, A. Cancer statistics, 2020. CA Cancer J. Clin. 2020, 70, 7-30. [CrossRef] [PubMed]

2. Simoes, M.C.F.; Sousa, J.J.S.; Pais, A. Skin cancer and new treatment perspectives: A review. Cancer Lett. $2015,357,8-42$. [CrossRef] [PubMed]

3. Apalla, Z.; Lallas, A.; Sotiriou, E.; Lazaridou, E.; Ioannides, D. Epidemiological trends in skin cancer. Dermatol. Pract. Concept. 2017, 7, 1-6. [CrossRef] [PubMed]

4. Schumacher, T.N.; Schreiber, R.D. Neoantigens in cancer immunotherapy. Science 2015, 348, 69-74. [CrossRef]

5. Bhandaru, M.; Rotte, A. Monoclonal antibodies for the treatment of melanoma: Present and future strategies. Methods Mol. Biol. 2019, 1904, 83-108. [CrossRef]

6. Ny, L.; Hernberg, M.; Nyakas, M.; Koivunen, J.; Oddershede, L.; Yoon, M.; Wang, X.; Guyot, P.; Geisler, J. Braf mutational status as a prognostic marker for survival in malignant melanoma: A systematic review and meta-analysis. Acta Oncol. 2020, 59, 833-844. [CrossRef]

7. Middleton, G. Beyond ipilimumab: A review of immunotherapeutic approaches in clinical trials in melanoma. Immunother. Adv. 2020, 1. [CrossRef]

8. Wilkes, J.G.; Patel, A.; McClure, E.; Pina, Y.; Zager, J.S. Developments in therapy for brain metastases in melanoma patients. Expert Opin. Pharmacother. 2021. [CrossRef]

9. Privat-Maldonado, A.; Schmidt, A.; Lin, A.; Weltmann, K.D.; Wende, K.; Bogaerts, A.; Bekeschus, S. Ros from physical plasmas: Redox chemistry for biomedical therapy. Oxid. Med. Cell. Longev. 2019, 2019, 9062098. [CrossRef]

10. Boeckmann, L.; Bernhardt, T.; Schafer, M.; Semmler, M.L.; Kordt, M.; Waldner, A.C.; Wendt, F.; Sagwal, S.; Bekeschus, S.; Berner, J.; et al. Current indications for plasma therapy in dermatology. Hautarzt 2020, 71, 109-113. [CrossRef]

11. Brany, D.; Dvorska, D.; Halasova, E.; Skovierova, H. Cold atmospheric plasma: A powerful tool for modern medicine. Int. J. Mol. Sci. 2020, 21, 2932. [CrossRef] [PubMed]

12. Dai, X.; Bazaka, K.; Thompson, E.W.; Ostrikov, K.K. Cold atmospheric plasma: A promising controller of cancer cell states. Cancers 2020, 12, 3360. [CrossRef]

13. Von Woedtke, T.; Schmidt, A.; Bekeschus, S.; Wende, K.; Weltmann, K.D. Plasma medicine: A field of applied redox biology. In Vivo 2019, 33, 1011-1026. [CrossRef]

14. Arndt, S.; Wacker, E.; Li, Y.F.; Shimizu, T.; Thomas, H.M.; Morfill, G.E.; Karrer, S.; Zimmermann, J.L.; Bosserhoff, A.K. Cold atmospheric plasma, a new strategy to induce senescence in melanoma cells. Exp. Dermatol. 2013, 22, 284-289. [CrossRef]

15. Azzariti, A.; Iacobazzi, R.M.; Di Fonte, R.; Porcelli, L.; Gristina, R.; Favia, P.; Fracassi, F.; Trizio, I.; Silvestris, N.; Guida, G.; et al. Plasma-activated medium triggers cell death and the presentation of immune activating danger signals in melanoma and pancreatic cancer cells. Sci. Rep. 2019, 9, 4099. [CrossRef] [PubMed]

16. Binenbaum, Y.; Ben-David, G.; Gil, Z.; Slutsker, Y.Z.; Ryzhkov, M.A.; Felsteiner, J.; Krasik, Y.E.; Cohen, J.T. Cold atmospheric plasma, created at the tip of an elongated flexible capillary using low electric current, can slow the progression of melanoma. PLoS ONE 2017, 12, e0169457. [CrossRef] [PubMed]

17. Bombelli, F.B.; Webster, C.A.; Moncrieff, M.; Sherwood, V. The scope of nanoparticle therapies for future metastatic melanoma treatment. Lancet Oncol. 2014, 15, e22-e32. [CrossRef]

18. Chilla, A.; Margheri, F.; Biagioni, A.; Del Rosso, T.; Fibbi, G.; Del Rosso, M.; Laurenzana, A. Cell-mediated release of nanoparticles as a preferential option for future treatment of melanoma. Cancers 2020, 12, 1771. [CrossRef] [PubMed]

19. Raja, G.; Jang, Y.-K.; Suh, J.-S.; Kim, H.-S.; Ahn, S.H.; Kim, T.-J. Microcellular environmental regulation of silver nanoparticles in cancer therapy: A critical review. Cancers 2020, 12, 664. [CrossRef]

20. Fan, M.; Han, Y.; Gao, S.; Yan, H.; Cao, L.; Li, Z.; Liang, X.-J.; Zhang, J. Ultrasmall gold nanoparticles in cancer diagnosis and therapy. Theranostics 2020, 10, 4944. [CrossRef]

21. Soetaert, F.; Korangath, P.; Serantes, D.; Fiering, S.; Ivkov, R. Cancer therapy with iron oxide nanoparticles: Agents of thermal and immune therapies. Adv. Drug Del. Rev. 2020, 163-164, 65-83. [CrossRef] [PubMed]

22. Siemer, S.; Westmeier, D.; Barz, M.; Eckrich, J.; Wunsch, D.; Seckert, C.; Thyssen, C.; Schilling, O.; Hasenberg, M.; Pang, C.; et al. Biomolecule-corona formation confers resistance of bacteria to nanoparticle-induced killing: Implications for the design of improved nanoantibiotics. Biomaterials 2019, 192, 551-559. [CrossRef] [PubMed]

23. Bekeschus, S.; Schmidt, A.; Weltmann, K.-D.; von Woedtke, T. The plasma jet kinpen-A powerful tool for wound healing. Clin. Plas. Med. 2016, 4, 19-28. [CrossRef]

24. Reuter, S.; von Woedtke, T.; Weltmann, K.D. The kinpen-a review on physics and chemistry of the atmospheric pressure plasma jet and its applications. J. Phys. D Appl. Phys. 2018, 51. [CrossRef]

25. Bekeschus, S.; Schmidt, A.; Niessner, F.; Gerling, T.; Weltmann, K.D.; Wende, K. Basic research in plasma medicine-A throughput approach from liquids to cells. J. Vis. Exp 2017, e56331. [CrossRef] 
26. Gandhirajan, R.K.; Endlich, N.; Bekeschus, S. Zebrafish larvae as a toxicity model in plasma medicine. Plasma Process. Polym. 2020, 18, e2000188. [CrossRef]

27. Gao, H.; Fan, P.; Xu, Q.; Li, Y.; Wang, J.; Weng, J.; Zhou, J.; Feng, B. In vitro and in vivo antitumor activity of silver nanoparticles on b16 melanoma. Nano 2020, 15, 2050163. [CrossRef]

28. An, M.; Yu, C.; Xi, J.; Reyes, J.; Mao, G.; Wei, W.-Z.; Liu, H. Induction of necrotic cell death and activation of sting in the tumor microenvironment via cationic silica nanoparticles leading to enhanced antitumor immunity. Nanoscale 2018, 10, 9311-9319. [CrossRef]

29. Zavisova, V.; Koneracka, M.; Kovac, J.; Kubovcikova, M.; Antal, I.; Kopcansky, P.; Bednarikova, M.; Muckova, M. The cytotoxicity of iron oxide nanoparticles with different modifications evaluated in vitro. J. Magn. Magn. Mater. 2015, 380, 85-89. [CrossRef]

30. Vinardell, M.P.; Mitjans, M. Antitumor activities of metal oxide nanoparticles. Nanomaterials 2015, 5, 1004-1021. [CrossRef]

31. Lagopati, N.; Evangelou, K.; Falaras, P.; Tsilibary, E.-P.C.; Vasileiou, P.V.S.; Havaki, S.; Angelopoulou, A.; Pavlatou, E.A.; Gorgoulis, V.G. Nanomedicine: Photo-activated nanostructured titanium dioxide, as a promising anticancer agent. Pharmacol. Ther. 2021, 222, 107795. [CrossRef]

32. Nakamura, K.; Yoshikawa, N.; Yamaguchi, Y.; Kagota, S.; Shinozuka, K.; Kunitomo, M. Characterization of mouse melanoma cell lines by their mortal malignancy using an experimental metastatic model. Life Sci. 2002, 70, 791-798. [CrossRef]

33. Shimokawa-Kuroki, R.; Sadano, H.; Taniguchi, S.I. A variant actin ( $\beta \mathrm{m})$ reduces metastasis of mouse b16 melanoma. Int. J. Cancer 1994, 56, 689-697. [CrossRef] [PubMed]

34. Sadano, H.; Inoue, M.; Taniguchi, S.I. Differential expression of vinculin between weakly and highly metastatic b16-melanoma cell lines. Jpn. J. Cancer Res. 1992, 83, 625-630. [CrossRef] [PubMed]

35. Ziegler, W.H.; Gingras, A.R.; Critchley, D.R.; Emsley, J. Integrin connections to the cytoskeleton through talin and vinculin. Biochem. Soc. Trans. 2008, 36, 235-239. [CrossRef]

36. Ahn, H.J.; Kim, K.I.; Hoan, N.N.; Kim, C.H.; Moon, E.; Choi, K.S.; Yang, S.S.; Lee, J.S. Targeting cancer cells with reactive oxygen and nitrogen species generated by atmospheric-pressure air plasma. PLoS ONE 2014, 9, e86173. [CrossRef]

37. Aryal, S.; Bisht, G. New paradigm for a targeted cancer therapeutic approach: A short review on potential synergy of gold nanoparticles and cold atmospheric plasma. Biomedicines 2017, 5, 38. [CrossRef]

38. Kong, M.; Keidar, M.; Ostrikov, K. Plasmas meet nanoparticles-Where synergies can advance the frontier of medicine. J. Phys. D Appl. Phys. 2011, 44, 174018. [CrossRef]

39. Choi, B.B.; Kim, M.S.; Kim, U.K.; Hong, J.W.; Lee, H.J.; Kim, G.C. Targeting neu protein in melanoma cells with non-thermal atmospheric pressure plasma and gold nanoparticles. J. Biomed. Nanotechnol. 2015, 11, 900-905. [CrossRef]

40. Cheng, X.Q.; Murphy, W.; Recek, N.; Yan, D.Y.; Cvelbar, U.; Vesel, A.; Mozetic, M.; Canady, J.; Keidar, M.; Sherman, J.H. Synergistic effect of gold nanoparticles and cold plasma on glioblastoma cancer therapy. J. Phys. D Appl. Phys. 2014, 47, 335402. [CrossRef]

41. Irani, S.; Shahmirani, Z.; Atyabi, S.M.; Mirpoor, S. Induction of growth arrest in colorectal cancer cells by cold plasma and gold nanoparticles. Arch. Med. Sci. 2015, 11, 1286-1295. [CrossRef]

42. Cheng, X.Q.; Rajjoub, K.; Sherman, J.; Canady, J.; Recek, N.; Yan, D.Y.; Bian, K.; Murad, F.; Keidar, M. Cold plasma accelerates the uptake of gold nanoparticles into glioblastoma cells. Plasma Process. Polym. 2015, 12, 1364-1369. [CrossRef]

43. He, Z.; Liu, K.; Scally, L.; Manaloto, E.; Gunes, S.; Ng, S.W.; Maher, M.; Tiwari, B.; Byrne, H.J.; Bourke, P.; et al. Cold atmospheric plasma stimulates clathrin-dependent endocytosis to repair oxidised membrane and enhance uptake of nanomaterial in glioblastoma multiforme cells. Sci. Rep. 2020, 10, 6985. [CrossRef]

44. Jawaid, P.; Rehman, M.U.; Zhao, Q.-L.; Misawa, M.; Ishikawa, K.; Hori, M.; Shimizu, T.; Saitoh, J.-I.; Noguchi, K.; Kondo, T. Small size gold nanoparticles enhance apoptosis-induced by cold atmospheric plasma via depletion of intracellular gsh and modification of oxidative stress. Cell Death Discov. 2020, 6, 1-12. [CrossRef]

45. Wende, K.; von Woedtke, T.; Weltmann, K.D.; Bekeschus, S. Chemistry and biochemistry of cold physical plasma derived reactive species in liquids. Biol. Chem. 2018, 400, 19-38. [CrossRef]

46. Akter, M.; Jangra, A.; Choi, S.A.; Choi, E.H.; Han, I. Non-thermal atmospheric pressure bio-compatible plasma stimulates apoptosis via p38/mapk mechanism in u87 malignant glioblastoma. Cancers 2020, 12, 245. [CrossRef] [PubMed]

47. Ahn, H.J.; Kim, K.I.; Kim, G.; Moon, E.; Yang, S.S.; Lee, J.S. Atmospheric-pressure plasma jet induces apoptosis involving mitochondria via generation of free radicals. PLoS ONE 2011, 6, e28154. [CrossRef] [PubMed]

48. Kang, S.U.; Cho, J.H.; Chang, J.W.; Shin, Y.S.; Kim, K.I.; Park, J.K.; Yang, S.S.; Lee, J.S.; Moon, E.; Lee, K.; et al. Nonthermal plasma induces head and neck cancer cell death: The potential involvement of mitogen-activated protein kinase-dependent mitochondrial reactive oxygen species. Cell Death Dis. 2014, 5, e1056. [CrossRef] [PubMed]

49. Saito, K.; Asai, T.; Fujiwara, K.; Sahara, J.; Koguchi, H.; Fukuda, N.; Suzuki-Karasaki, M.; Soma, M.; Suzuki-Karasaki, Y. Tumorselective mitochondrial network collapse induced by atmospheric gas plasma-activated medium. Oncotarget 2016, 7, 19910-19927. [CrossRef]

50. Kaushik, N.K.; Kaushik, N.; Park, D.; Choi, E.H. Altered antioxidant system stimulates dielectric barrier discharge plasma-induced cell death for solid tumor cell treatment. PLoS ONE 2014, 9, e103349. [CrossRef]

51. Ma, J.; Yu, K.N.; Cheng, C.; Ni, G.; Shen, J.; Han, W. Targeting nrf2-mediated heme oxygenase-1 enhances non-thermal plasmainduced cell death in non-small-cell lung cancer a549 cells. Arch. Biochem Biophys 2018, 658, 54-65. [CrossRef] 
52. Schmidt, A.; Rodder, K.; Hasse, S.; Masur, K.; Toups, L.; Lillig, C.H.; von Woedtke, T.; Wende, K.; Bekeschus, S. Redox-regulation of activator protein 1 family members in blood cancer cell lines exposed to cold physical plasma-treated medium. Plasma Process. Polym. 2016, 13, 1179-1188. [CrossRef]

53. Keenan, C.R.; Goth-Goldstein, R.; Lucas, D.; Sedlak, D.L. Oxidative stress induced by zero-valent iron nanoparticles and fe(ii) in human bronchial epithelial cells. Environ. Sci. Technol. 2009, 43, 4555-4560. [CrossRef] [PubMed]

54. Madkour, L.H. Nanoparticles Induce Oxidative and Endoplasmic Reticulum Stresses; Springer: Cham, Switzerland, 2020.

55. Manke, A.; Wang, L.; Rojanasakul, Y. Mechanisms of nanoparticle-induced oxidative stress and toxicity. Biomed. Res. Int. 2013, 2013, 942916. [CrossRef] [PubMed]

56. Jalili, A.; Irani, S.; Mirfakhraie, R. Combination of cold atmospheric plasma and iron nanoparticles in breast cancer: Gene expression and apoptosis study. Onco Targets Ther. 2016, 9, 5911-5917. [CrossRef] [PubMed]

57. Dzimitrowicz, A.; Bielawska-Pohl, A.; diCenzo, G.C.; Jamroz, P.; Macioszczyk, J.; Klimczak, A.; Pohl, P. Pulse-modulated radiofrequency alternating-current-driven atmospheric-pressure glow discharge for continuous-flow synthesis of silver nanoparticles and evaluation of their cytotoxicity toward human melanoma cells. Nanomaterials 2018, 8, 398. [CrossRef] [PubMed]

58. Dzimitrowicz, A.; Bielawska-Pohl, A.; Jamroz, P.; Dora, J.; Krawczenko, A.; Busco, G.; Grillon, C.; Kieda, C.; Klimczak, A.; Terefinko, D.; et al. Activation of the normal human skin cells by a portable dielectric barrier discharge-based reaction-discharge system of a defined gas temperature. Plasma Chem. Plasma Process. 2019, 40, 79-97. [CrossRef]

59. Manaloto, E.; Gowen, A.A.; Lesniak, A.; He, Z.; Casey, A.; Cullen, P.J.; Curtin, J.F. Cold atmospheric plasma induces silver nanoparticle uptake, oxidative dissolution and enhanced cytotoxicity in glioblastoma multiforme cells. Arch. Biochem. Biophys. 2020, 689, 108462. [CrossRef] 